\title{
白色有機 EL 照明下での色弁別特性
}

\author{
正会員 山内 泰樹（山形大学） 坂田 勝亮（女子美術大学） 正会員 平澤 正勝（山形大学）
}

\section{Color Discrimination Under White Organic Electroluminescence Illumination}

\author{
Member Yasuki Yamauchi (Yamagata University), Katsuaki Sakata (Joshibi University of Art and Design), \\ and Member Masakatsu Hirasawa (Yamagata University)
}

\begin{abstract}
Organic EL (OLED) has been attracting attention as a next-generation lighting fixture that can achieve high energy efficiency. One of the advantages of OLED is that there is a lot of flexibility in terms of choosing which organic materials to use, which in turm creates various spectral distributions of light. For this purpose, it is important to evaluate the performances of color perception under OLEDs. In this research, we measured the color discrimination performance under a prototype OLED light and compared the results with those derived under fluorescent light and under a commercially available LED lamp. Some observers had more difficulty discriminating color under OLED compared with under D65 fluorescent light. Although the spectral distributions of the light sources were different, the performances did not indicate any statistically significant hue dependences.
\end{abstract}

KEYWORDS: OLED illumination, Organic Electroluminescence illumination, color discrimination, color perception

\section{1 緒言}

近年の省エネルギー化の流れは大震災後に加速し，照明にも大き な影響をあたえている．次世代照明光源として消費電力が少ない LED(Light-Emitting Diode)照明や, 理論的な効率限界が蛍光ラン プの 2 倍程度に達する有機 EL 照明などが期待され, LED 照明では ここ半年ほどで市場への急速な導入が進んでいる，一方，有機 EL 照明も次世代代替光源として, 現在照明効率やパネル・材料寿命な どに関する研究は着実に進んでいる 1) 2) が, 面発光光源であること, 基材にプラスチックシートを用いフレキシブル照明を実現できる こと 3), 電極を透明化した透明な照明器具が可能 4)であるなど, 従 来照明とは異なる特徵を有することもあり, 主照明代替以外にも新 たな照明アプリケーションを生み出すキーテクノロジーとして注 目を集め, 年内にも多くの企業からの試験的な商品出荷と、数年内 の普及が見込まれている.

有機 EL 照明は，有機物質に印加することにより発光する現象を 用いた照明デバイスの総称であり, 有機材料特有の発光波長・帯域 の広い選択性と複数の材料の適切な組み合わせにより, 任意の光源 分光分布を設計することができる．RGB に発光領域を有する 3 種 類の有機物質を積層した三色型白色有機 EL 照明が発明されてから 5), 発光材料の他にも電子・正孔伝導材料や多層化積層技術 6)の改 善が図られドーピング技術の進展とともに、その輝度向上やエネル ギー効率の改善がなされてきた 1) 6). 上記のように白色有機 EL 照 明の分光分布は材料によって決定されるが, 現時点でのサンプル出 荷製品や今後出荷されると期待される初期製品では, 青色発光材料
の制約から, 短波長領域特に $450 \mathrm{~nm}$ 以下の成分があまり含まれ ない. このような分光分布特徴をもつ有機 EL 照明は, 実用化に 向けその照明下での色知覚特性をあらかじめ実験的に把握して おく必要がある.

我々は, 通常ある照明下に置かれるとその照明に順応し, 照明 の色度が変化しても色の知覚はその影響をあまり受けない。これ は色恒常性として知られ, 白色が白色として知覚されるように作 用するといわれている7) 8). 特に照明が $\mathrm{D}_{65}$ 照明から大きく変化 しても，色のカテゴリーは保持されること9)が知られている．こ のような色恒常性のメカニズムとしては錐体の感度を照明光に 合わせて変化させるという von Kries 型モデルが知られている 10).このようなモデルでは, 錐体の受光量が支配的な要因となり, 照明光の分光分布には影響を受けないので, 短波長成分に特徵を 有する有機 EL 照明であっても，色度がある範囲にあればほぼ同 じ色知覚になることが予想される．色が同じかどうかを区別する 色の弁別に関しても，視覚系が錐体信号だけを用いて色の弁別を 行っているのであれば, 入射光の分光分布は影響を与えないはず であるが，ある波長成分の光が色弁別に有効に作用しているとす れば, 色度図上の距離で表記される色差だけでは色弁別特性を記 述することはできないことが予想される.

また，近年では照明の演色性も問題になってきている．演色性と は照明が異なるときにどの程度色が正確に再現されるか色差を 用いて定量的に計算したものであるが，LED などの個体照明光 源では, 主観的な色再現評価結果と, この演色指数が必ずしも一 致した傾向を示さないことが報告されている ${ }^{11)}$. そのため, 従来 
の演色指数と色の見え具合の不一致から国際照明委員会 $(\mathrm{CIE})$ で も新しい演色指数の検討がなされてきている 12). 有機 EL 照明は, 材料の選択により発光波長が変化するが, 全体としては急峻な分 光分布を有するケースは少ないので, 演色指数は高めになると思 われる. 現在の指標の值と色弁別特性との関係は, 次に紹介する ような先行研究があるが, 有機 ELについても明らかにしておく必 要があろう。

次世代照明デバイス下での色知覚に関する先行研究としては, Mahler らによるLED におけるものがある13)。彼らは，種々の異 なる LED 下で, 色弁別と演色性を評価し, 特に RGB タイプの LED ランプの色弁別が劣っているという報告を行っている. また, Szabo らも，LED 照明下で FM-100 hue テストを実施し， RGB タイプの LED でのスコアが高い（色弁別性が悪い）と報告してい る 14).これらの研究報告は, 色知覚特性の中でも少なくとも色弁 別特性については, 照明の色度だけではなく, その構成する分光 成分も影響を与えている，ということを示唆する。

本研究は, 色弁別特性に着目し, プロトタイプとして作成された 白色有機 EL 照明下での色弁別特性を調べた. そして, 従来光源で ある蛍光ランプや最近になって急速に普及が進んでいる LED 照 明下で同じ実験を行い, その色弁別特性を本実験の結果と比較し, 発光波長特性が大きく異なる有機 EL 下での色弁別特性に関して 調べることを目的とする．上述したように，有機 EL では $450 \mathrm{~nm}$ 以下の短波長成分を有さないため, 短波長成分である紫から青成 分にかけての弁別特性が悪いことが予想される.この予想を実験 的に検証し, どの程度の特性なのか, 他の照明における弁別特性 との比較を行う。

\section{2. 実験}

\section{1 実験装置と実験に用いた照明の特性}

実験に用いたブース内で設置された照明光源の配置を図 1 に示 す. ブースは幅 150 センチ×奥行き 90 センチ×高さ 180 センチ であり, 壁面が暗幕で覆われている.ブース天井には $\mathrm{D}_{65}$ 蛍光ラ ンプ, 白色 LED (シャープ, 電球型 LED ランプ), 有機 EL の 3 種類が設置され，それぞれが独立に制御できるようになっている. それぞれの照明の分光分布をトプコン SR-3A 分光放射輝度計を用 いて机上面で測定したものが図 2 である。黒の太実線, グレイの 実線, 黒細線がそれぞれ有機 EL, 白色 LED, D 65 蛍光ランプを表 す.また, 照明の三刺激值, $\mathrm{xy}$ 色度, 色温度を表 1 に示寸. ここ から, 明らかなように, 有機 EL では短波長成分が他の照明と異な り, 特に $450 \mathrm{~nm}$ 以下の成分がほとんど存在しないことがわかる. また, 机上面の照度は, 全ての照明でほぼ同等の照度（約 6001x） となるように, 発光強度が調整された。

\section{2 実験刺激}

色弁別特性を求めるのに, 日本色研事業（株）で供給している ND-100 (100 色相配列検查器)を刺激として使用した. これらの刺 激は, 本来は色覚検查に用いられるものである.これらは FM-100 hue test と同様に 25 色の色コマを色相が徐々に変わるように並心゙ 替えて色覚検查を行う用途で開発されたものであるが，本研究で は，色弁別特性を測定するプローブとして用いた. 100 hue test では，スコアの計算に隣接する色コマ同士に付された番号（数字） の差を用いる. 色相の変化を色コマで正しく並べることができれ ば, 隣接するコマ同士の数字の違いは 1 になるが, 正しくない位 置に色コマが置かれると, 隣接する色コマとの数字の違いが大き (a)

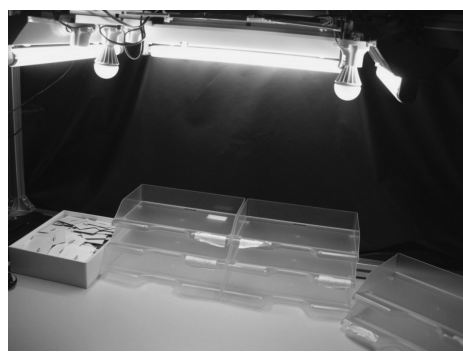

(b)

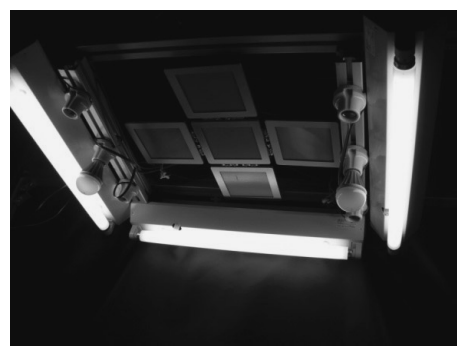

図 1 実験ブース内部(a)と照明の配置(b). 中央十字に置かれているのが 有機 EL 照明.

Fig. 1 Experimental booth and illuminations used in the experiments. Square panels in the center are OLED lights.

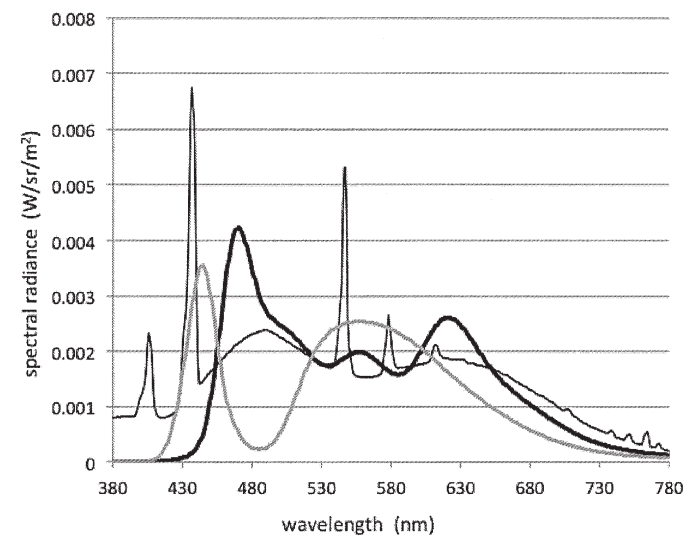

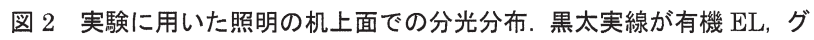
レイの実線が LED, 黒細線が $\mathrm{D}_{65}$ の分光分布をそれぞれ表す.

Fig. 2 Spectral distributions of the illuminations used in the experiments. Black solid line, gray solid line and black thin line denotes OLED, LED, and D65 fluorescent lamp, respectively.

\section{表 1 各照明の三刺激值と $\mathrm{xy}$ 色度, ならびに色温度}

Table 1 Tristimulus values, $x y$ chromaticities and CCT of each illumination.

\begin{tabular}{|c|c|c|c|c|c|c|}
\hline 照明光源 & $\mathrm{X}$ & $\mathrm{Y}$ & $\mathrm{Z}$ & $\mathrm{x}$ & $\mathrm{y}$ & $\mathrm{CCT}$ \\
\hline 有機 EL 照明 & 155.8 & 161.3 & 140.0 & 0.337 & 0.354 & 5330 \\
\hline LED & 166.5 & 171.4 & 140.2 & 0.348 & 0.358 & 4920 \\
\hline $\mathrm{D}_{65}$ 蛍光灯 & 165.4 & 171.5 & 193.6 & 0.311 & 0.323 & 6626 \\
\hline
\end{tabular}


くなり，並べ違えが生じた色コマが表すスコアは高くなる．もと もと隣接する色コマ同士の色差がさほど大きくないので, ある照 明下で特定の色相成分の色弁別が困難であれば，その領域の色コ マ同士の並べ替えタスクにおける成績は低下し, その結果得られ るスコアが高くなる（=色弁別特性が悪化し, 正しい順序で並べ られない）ことが予測される. 実験に用いた各照明下で測光した 結果を xy 平面にプロットしたものを図3に示す.

\section{3 実験手順}

被験者は，まず実験ブースの中に入り，実験に用いる照明下で 5 分間順応する。 それに続いて, 色弁別実験を実施した。 ND-100 は 4 本のケースに 27 個ずつの色コマが刺激として格納されてい るが, 被験者は両端の 2 色をアンカーとして, 両者の間の色の変 化が滑らかになるように, 寸なわち色相が順に変化するように 2 5 個の色コマを並べ替えるように教示された。一般的に色覚検查 に用いられる時にはこの 25 個の並べ替えを 2 分間で実施するよう に設定されているが, 本研究では, 色覚検査を行うことが目的で はなかったため，3 分間を実験時間として採用した. 実際の調整は 3 分間以内で終了し, 全ての被験者が満足する色の調整を行うこと ができた.

全ての被験者は, 各照明に対して 2 回ずつの色弁別実験を実施 した. 基本的には $\mathrm{D}_{65}$, 有機 $\mathrm{EL}, \mathrm{LED}$ の順に行ったが, 順序の異 なる被験者もいた。しかし，この場合も同一の照明下での実験を 2 回連続して行うことは避けた。

\section{4 被験者}

被験者は, 色覚正常な 11 名（男性：8名, 女性：3名）であり, 20 代から 50 代であった. 各被験者について D-15 パネルテストに より色覚正常であることを実験前に確認した。 全被験者とも, こ のような色コマの並べ替えなどの色彩に関する心理物理実験を実 施した経験がない Naïve な被験者であった。

\section{3. 結果}

色弁別スコアの結果は, 被験者ごとに大きく異なった。傾向とし

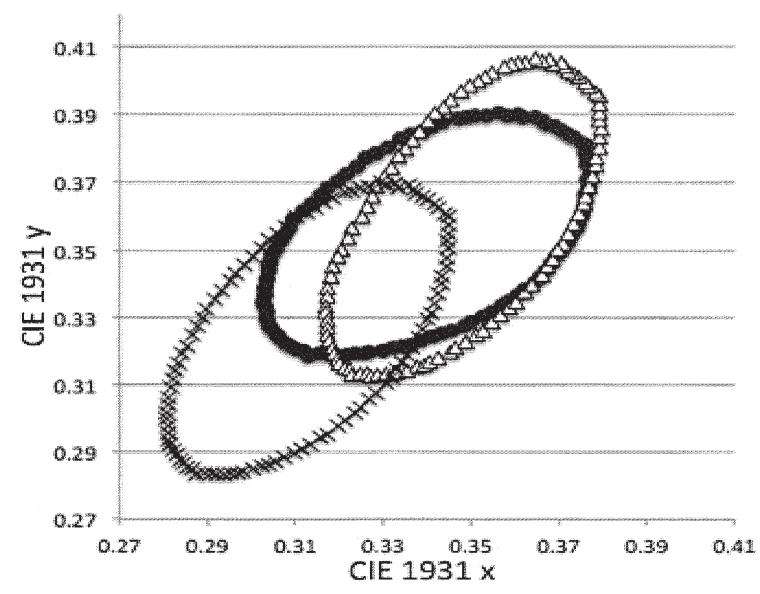

図 3 実験に用いた ND-100 色コマの各照明下での色度. ○が有機 $\mathrm{EL}, \triangle$ が LED， ×が $\mathrm{D}_{65}$ 巣光ランプ下での測定值を表す.

Fig. 3 Chromaticities of ND-100 color chips. $, \triangle, \times$ symbols denote OLED, LED, D65 fluorescent lamp, respectively.

て，有機 EL 下でのスコアを $\mathrm{D}_{65}$ 下でのスコアと比較して，1） 優れていた $: 2$ 名, 2 ) 同等 $: 3$ 名, 3 ) 劣っている: 7 名, のパ ターンに分けることができた。 それぞれのパターンで代表的な結 果を図 4 に示す. 各照明下でのスコアをプロットしたものであり, 黒太実線, グレイ実線, 黒細線がそれぞれ有機 EL, 白色 LED, $\mathrm{D}_{65}$ 蛍光ランプの結果を表す. (a), (b)，(c)がそれぞれ上述した 1 )， 2), 3 ）に対応する. 円周方向には色コマの番号を表し, 軸方向 がスコアを表す。 また, ケースごとにどの色相が呈示されていた かを図中にケース番号とともに矢印で示す. 各被験者は, この範 囲の色を一度に呈示されて, 色相順に並べ替えた。

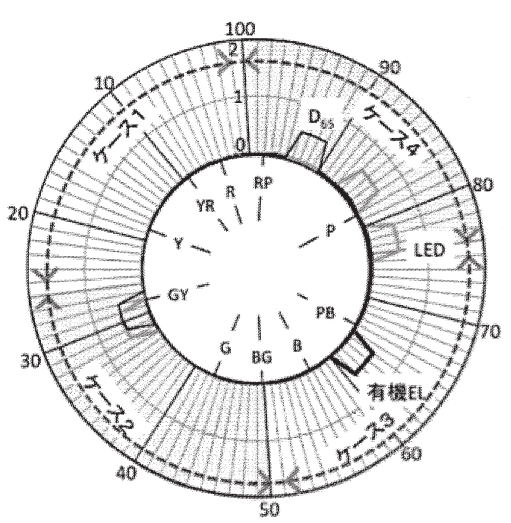

(a)

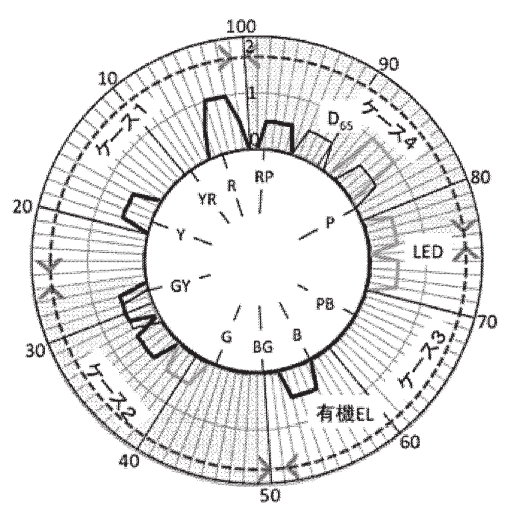

(b)

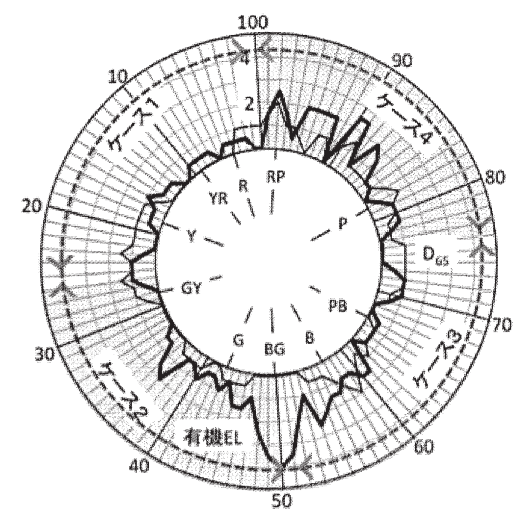

(c)

図 4 色弁別実験の結果.（a）有機 EL のスコアが低かった,（b）有機 EL と他の照明でのスコアがほぼ同等，(c) 有機 EL のスコアが高かった，各被験 者の例. 黒太実線が有機 EL, グレイの線が LED, 黒細実線が $\mathrm{D}_{65}$ 蛍光ランプの結果を示す. 軸の数字がスコアを表し, 色コマの番号（1～100）が円周 方向に示されている. また, 中央部に記載された色相は, それぞれの色コマの色相である. ケース番号によって呈示された色コマが示されている.

Fig. 4 Experimental results. (a), (b), (c) indicates the score obtained by different observers where OLED is lower, equal, higher, respectively. Black bold solid line, gray solid line, and black thin solid line denote OLED, LED, D65, respectively. 


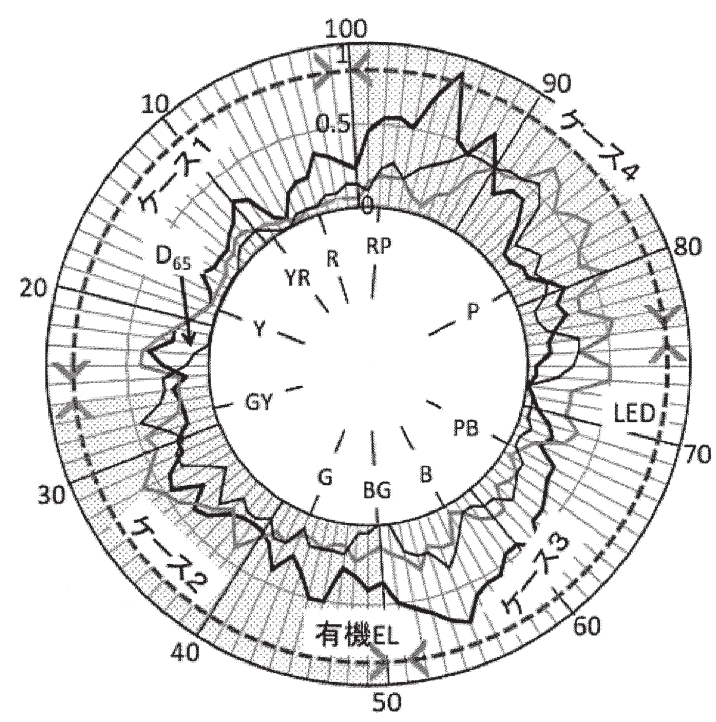

図 5 色弁別実験結果の全被験者の結果の平均値. 図中のシンボル等は 図 4 と同様である.

Fig. 5 Average scores of the color chips obtained in the experiments. The symbols are the same as Fig.4.

有機 EL 照明条件での結果から

・B B B にかけて, 及びその反対側の色相（RP 付近）のスコアが 高い（弁別が悪い）被験者が多い

・他の色相，特に GY Gにかけては，スコアが相対的に低い

ということが分かる.

被験者によっては，内観として「有機 ELでは，ある特定領域の 色コマの色が完全に見分けられなくなった」という報告があった が，必ずしもこのような感想は全員からは得られなかった．図３に おいて示されたように, 色度図上にほぼ均等に色コマが並んでいる にもかかわらず，そのような知覚が生じたということは，色弁別特 性を決定する要因が色差のように計算から得られるような值では なく，他の要因が主要因である可能性を示唆する．また，年齢が 高い被験者において色弁別スコアが高い傾向が見られた。年齢が高 くなるにつれ，色の弁別ができなくなったのか，時間的制約から長 時間の集中が困難であったために，このような結果になったのか， いずれにせよ興味深い傾向である。

全被験者の平均值をプロットしたのが図 5 である、これから，

・全体としては有機 EL 下でのスコアが高めである

・有機 EL と LED ではスコアが高い（色弁別が悪い）色相が異な る

・GY〜G 寄りの領域では，全ての照明で同様な傾向が見られ，ス コアが高めである

ことが分かる。

具体的には, $\mathrm{PB} \sim \mathrm{B} \sim \mathrm{BG}$ にかけての色相領域では有機 $\mathrm{EL}$ のス コアが高いが，Pを中心とした RP, PB にかけての色相においては LED のスコアが高い. RP から P にかかる色相では再度有機 EL の スコアが高めになるが, この領域の P 側では, 有機 EL だけでなく, LED， D 65 でもスコアが高かった。

図 5 に示したように，全被験者の平均スコアを見ると，有機 EL での色弁別特性が劣っているように見受けられる. それが統計的に
表 2 各被験者の光源，色相ごとのスコア小計

Table 2 Scores of each subject for all illumination.

\begin{tabular}{|c||c|c|c|c|c|c|c|c|c|c|c|c|}
\hline \multicolumn{1}{|c||}{} & \multicolumn{3}{c|}{ OLED } & \multicolumn{5}{c|}{ D65 } & \multicolumn{5}{|c|}{ LED } \\
\cline { 2 - 15 } & B1 & B2 & B3 & B4 & B1 & B2 & B3 & B4 & B1 & B2 & B3 & B4 \\
\hline \hline MH & 4 & 0 & 16 & 8 & 0 & 0 & 0 & 8 & 3 & 5 & 0 & 8 \\
\hline YI & 19 & 18 & 39 & 20 & 1 & 15 & 9 & 27 & 3 & 29 & 4 & 32 \\
\hline TF & 31 & 27 & 41 & 49 & 8 & 28 & 28 & 40 & 25 & 32 & 35 & 16 \\
\hline MT & 1 & 19 & 25 & 35 & 0 & 0 & 0 & 20 & 4 & 8 & 7 & 37 \\
\hline NI & 20 & 60 & 32 & 48 & 12 & 43 & 10 & 35 & 15 & 53 & 42 & 74 \\
\hline SS & 0 & 8 & 32 & 0 & 0 & 4 & 4 & 0 & 0 & 11 & 1 & 8 \\
\hline MS & 1 & 0 & 0 & 7 & 0 & 8 & 0 & 8 & 0 & 0 & 0 & 0 \\
\hline EW & 26 & 21 & 13 & 16 & 4 & 3 & 18 & 3 & 5 & 12 & 12 & 23 \\
\hline TW & 0 & 4 & 4 & 4 & 0 & 8 & 0 & 12 & 0 & 4 & 8 & 0 \\
\hline TH & 0 & 0 & 4 & 0 & 0 & 4 & 0 & 4 & 0 & 4 & 0 & 8 \\
\hline RY & 12 & 8 & 4 & 4 & 0 & 4 & 0 & 8 & 0 & 4 & 3 & 13 \\
\hline
\end{tabular}

表 3 分散分析表. $5 \%$ 有意な $\mathrm{F}$ 值に*を付した

Table 3 ANOVA table. Significant difference of $5 \%$ is shown with an asterisk.

\begin{tabular}{|c|c|c|c|c|}
\hline 変動因 & SS & $\mathrm{Df}$ & MS & $\mathrm{F}$ \\
\hline 被験者：S & 16848.97 & 4 & 4212.24 & \\
\hline $\begin{array}{r}\text { 主効果：A } \\
\text { (照明タイプ) }\end{array}$ & 1056.24 & 2 & 528.12 & $7.970^{*}$ \\
\hline 誤差 : $\mathrm{A} \times \mathrm{S}$ & 530.12 & 8 & 66.27 & \\
\hline $\begin{array}{c}\text { 主効果 : B } \\
\text { (色相) }\end{array}$ & 2274.97 & 3 & 758.32 & 2.547 \\
\hline 誤差 : $\mathrm{B} \times \mathrm{S}$ & 3572.36 & 12 & 297.70 & \\
\hline $\begin{array}{c}\text { 交互作用： } \\
\mathrm{A} \times \mathrm{B}\end{array}$ & 530.12 & 6 & 88.35 & 0.664 \\
\hline $\begin{array}{c}\text { 誤差 : } \\
\mathrm{A} \times \mathrm{B} \times \mathrm{S}\end{array}$ & 3192.55 & 24 & 133.02 & \\
\hline 全体：T & 28005.33 & 59 & & \\
\hline
\end{tabular}

有意な違いかどうか，分散分析を用いて検定を行うことにする. ここでは，照明の種類と色相を 2 つ要因として扱う．全被験者 が全実験に参加したので，これは，2 要因の乱塊法に相当する。

表 2 に示したのが，各被験者の色相ごとのスコアである. 要因 A を照明タイプ ( 3 種類), 要因 B を色相 (100 hue test のケー スごとの 4 種類）とし, 被験者 11 名のデータを表したものであ る.

この表をもとに, 分散分析を行い, 分散分析表を作成した. 分 散分析表を表 $3 に$ 示す. これをみると, 照明タイプを主効果とし たときが $5 \%$ 有意となっていることがわかる．その他の効果であ る色相は $5 \%$ 有意ではない. また, 交互作用についても有意な違 いでないことがわかる.また, 下位検定としてテューキーの HSD を行ったが，いずれも有意ではなかった。

\section{4. 考察}

上述したように，短波長成分を含まない有機 EL 照明下での色 


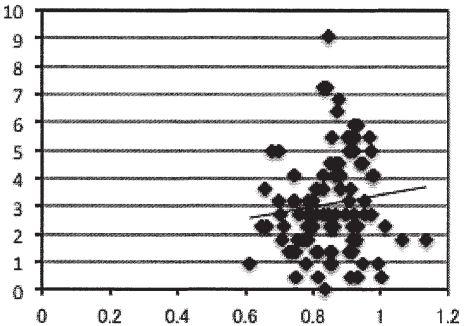

(a)

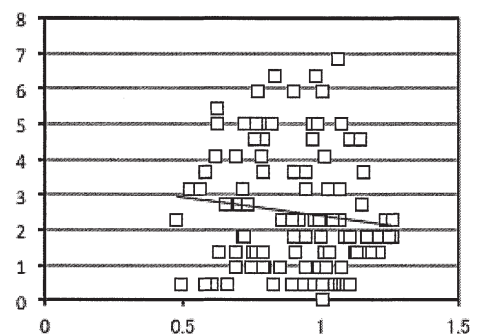

(b)

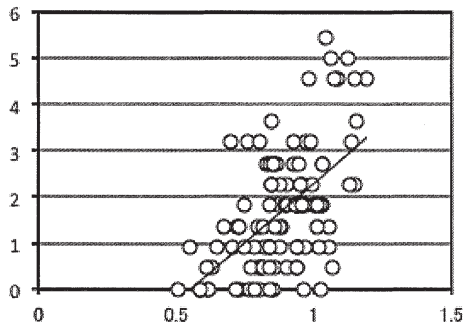

(c)

図 6 色差とスコアの関係を示したもの. 横軸が隣接する色コマとの色差を表し, 縱軸はその色コマのスコアを表す．それぞれのパネルが異なる照明を表 す ((a): 有機 $\left.\mathrm{EL},(\mathrm{b}): \mathrm{LED},(\mathrm{c}): \mathrm{D}_{65}\right)$

Fig. 6 The relationship between color difference and scores. $X$ axis indicates the color difference, and $y$ axis indicates the scores of each color cap. Panel (a), (b) and (c) denote OLED, LED, D65, respectively.

弁別特性は, LED や $\mathrm{D}_{65}$ 蛍光ランプの下での色弁別特性とは若干 異なり，特に D65 蛍光ランプの特性と比較すると，色弁別特性が よくない被験者が多かった。しかしながら，短波長成分として 450nm 以下を含まないながらも，その領域に主波長を有する色相 では，有機 EL よりも LED の方が色弁別特性はよくない，という 実験結果が得られた。ND-100 の想定照明が今回のような LED や 有機 EL ではないため, シートに記載されている主波長通りの值と なっているか，更なる解析・検討が必要であるが，短波長成分から 純紫軌跡領域にかけては必ずしも有機 EL で弁別特性が悪いという 結果にはならなかった。ここでは，このような結果が測色した色差 から実験結果が説明できるかの検討を行う，考えられる仮説とし て, 色弁別性が悪い（スコアが高い）色コマでは, 隣接する色コマ 間の色差が小さくなっていることが原因で色弁別ができない，とい うものである. ND-100hue テストは C 光源下での使用を想定して 作成されており，本研究の実験で用いたそれぞれの照明の下での色 差に関しては，何ら保証されていないからである，そのため，照明 の分光分布に特徵がある場合には，隣接する色コマとの間の色差が 小さくなり，弁別しにくくなっている可能性もある.

色差を求めるため, 各色コマの三刺激值 XYZ から均等色空間で ある $\mathrm{L}^{*} \mathrm{a} * \mathrm{~b}$ *值に変換した，基準白色としては各照明下で机上にお いた標準白色板の三刺激值を各照明の三刺激值（表 1 に記載）とし て用いた。

図 6 に示したのは，隣接する色コマの $\mathrm{L}^{*} \mathrm{a}{ }^{*} \mathrm{~b}$ *值間のユークリッ ド距離で表される色差と，その色コマのスコアの関連を散布図にプ ロットしたものである. (a), (b)，(c)がそれぞれ有機 EL，LED， $\mathrm{D}_{65}$ 蛍光ランプ，の結果を表す，なお，各色コマの色差の值として は，両側に隣接する 2 つ色コマとの色差の平均值を計算し，その 值をその色コマのもつ色差とした.

色差とスコアに関する全体的な傾向として,

・色差が小さければスコアが高いということには，必ずしもならな い

・結果を一次近似すると，D65 下で多少の正の相関，LED 下では， 負の相関が見られた。ここで，「負の相関」は，色差が小さい方が 色弁別スコアが高いことを示すので，前述した仮説に一致する方向 であるが，ここで得られた決定係数 $\mathrm{R}^{2}$ は有機 $\mathrm{EL}, \mathrm{LED}, \mathrm{D}_{65}$ 蛍光 ランプにおいてそれぞれ $0.013 ， 0.014 ， 0.320$ と非常に小さく, 全 ての照明条件において, 色差と色弁別スコアの両者には相関性は全 くみられないといってよい.
図6に示したのは，全刺激に対する結果であった．図 5 に示され たように, LED や有機 EL では, 特定の色相においてスコアが高 かった。 その原因として，その特定領域においてだけ色差が小さ かった可能性もある. そのため, 特にスコアの高かった色相領域 （有機 EL の 43〜68 及び 93〜100, LED の 70 90）のデータ だけを図 7 にプロットした。これを見ると，特に色弁別特性が悪 かった特定の色相領域においても, 色差と色弁別スコアの間には 相関が見られないことが明らかである。

次に，色弁別特性と視覚特性との関連について考察する．実験

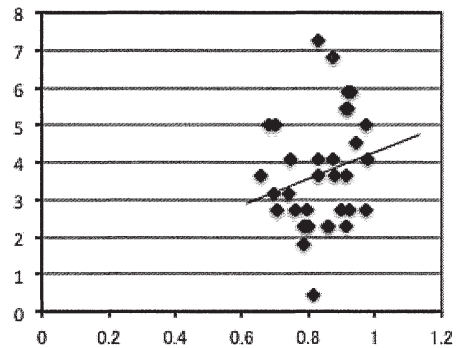

(a)

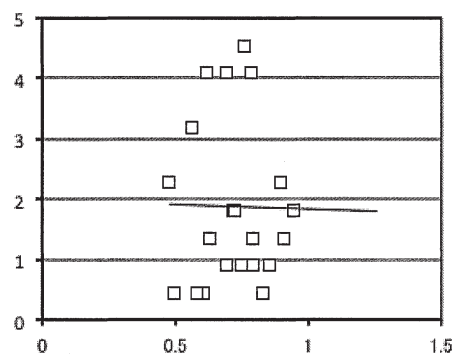

(b)

図 7 特定色相領域での色差と色弁別スコアを示したもの. 横軸 が隣接する色コマとの色差を, 縦軸はその色コマのスコアを表す.

Fig. 7 The relationship between color difference and scores of specific hues. See Figure 6 for detail. Panel (a) and (b) denote OLED and LED. 
結果については, 各被験者間の違いが大きかった。この原因の一つ として, 眼光学特性における個人差が作用していた可能性がある. 図 2 に示したように, 有機 EL の特徴として短波長成分が存在しな い, ということが挙げられた。この波長領域に感度を有するのは, 主として $\mathrm{S}$ 錐体であるが, 眼光学系でみれば, 網膜の手前に紫外線 成分を吸収するといわれている黄斑色素（Macular pigment）が存 在しており, この黄斑色素濃度には個人差が大きいことが知られて いる. 黄斑色素濃度が濃い被験者の方が, 短波長成分の透過量が少 なくなるために, 色弁別の成績が今ひとつ芳しくなかった可能性も ある.また, 被験者の年齢も関係していた可能性がある. 加齢に伴 ら視覚系の眼光学特性の変化として一番よく知られているものと しては，水晶体の黄濁化が挙げられる，黄濁化に伴い，短波長成分 の透過量が減ったために, 色弁別を行いにくかった可能性もある.

\section{5. 結言}

本研究では, 次世代照明用光源として期待されている有機 EL 照 明のプロトタイプを用いて, 色弁別特性を実験的に測定し, その結 果を LED 照明や $\mathrm{D}_{65}$ 蛍光ランプと比較した. 有機材料の選択によ り, 有機 EL のとりうる分光分布は非常に大きな選択肢があるが, $450 \mathrm{~nm}$ 以下の短波長成分を含まない，現在プロトタイプとして入 手可能である有機 EL 照明の下であっても, 特定の色相における色 弁別が低下寸ることについては, 統計的有意差は見られなかった. 有機 $\mathrm{EL} ， \mathrm{D}_{65}$ 蛍光ランプ， LED といった照明タイプの違いが色弁 別特性に有意であるという検定結果が得られたが，その原因が分光 分布だけであるのか, 他の要素が効いているのか, 今後照度レベル を変化させた実験や異なる分光分布を有する有機 ELを用いてさら に検討を進めて行きたい.

緒言でも述べたように, 固体照明光源に対する新しい演色指数に 関する検討が進められている，本研究では言及できなかったが，有 機 ELにおいても，この新しい演色性評価指数がごのような挙動を 示すかは将来的に検討する必要があろう。

\section{参考文献}

(1) Kamtekar K.T., Monkman A.P. and Bryce M.R. : Recent Advances in White Organic Light-Emitting Materials and Devices (WOLEDs), Advanced Materials, 22, pp. 572-582 (2010).

(2) http://www2.dupont.com/Displays/en_US/news_events/art icle20090527.htm (last access: 29 Aug. 2011).

(3) http://www.gelighting.com/eu/resources/press_room/OLED s.html (last access: 29 Aug. 2011).

(4) http://kaden.watch.impress.co.jp/cda/news/2009/03/05/36 20.html (last access: 29 Aug. 2011).

(5) Kido J., Kimura M. and Nagai K., Multilayer : White Light-Emitting Organic Electroluminescent Device, Science, 267 no. 5202, 1332-1334 (1995).

(6) Matsumoto T, Nakada T, Endo J, Mori K, Kavamura N, Yokoi A, Kido and J, Multiphoton : Organic EL device having Charge Generation Layer, SID Symposium Digest, 979-981 (2003).

(7) Wyszecki, G. and Stiles, W.S. : Color Science, 2nd ed., John Wiley \& Sons, New York, (1982).
(8) Kuriki, I. and Uchikawa, K. : Limitations of surface-color and apparent-color constancy, J. Opt. Soc. Am. A. 13, $1622 \cdot 1636$ (1996).

(9) Uchikawa, K. and Yamauchi, Y: Categorical color constancy is more tolerant than apparent color constancy. Progress in Biochemistry and Biophysics, 31 Supplement, 49 (2004).

(10) Fairchild, M. : Color Appearance Models, Addison Wesley Longman, Inc. (1998).

(11) Bodrogi, P., Csuti,, P., Szabo, F. and Schanda, J. : "Why does the CIE colour rendering index fail for white RGB LED light sources?" in Proc. of CIE Expert Symposium on LED Light Sources, Vienna, CIE, Tokyo (2004).

(12) Davis, W. and Ohno Y. : Towards an improved color rendering metric. Proc. Solid State Lighting V, SPIE 2005; 5941: 59411G1- 59411G8 (2005).

(13) Mahler, E., Ezrati, JJ and Vienot, F. : Testing LED Lighting for Colour Discrimination and Colour Rendering, Color Res. And Appl., 34, 8-17 (2009).

(14) Szabo, F., Schanda, J., Bodrogi, P. and Radkov, E. : A comparative study of new solid state light sources, Proc. CIE 26th Session 2007; D1: 18-21 (2007).

（受付日 2011 年 9 月 6 日/採録日 2011 年 12 月 5 日)

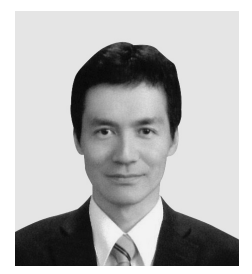

山内 泰樹（正会員）

山形大学大学院理工学研究科

干992-8510 山形県米沢市城南 4-3-16 1999 年東京工業大学大学院総合理工学 研究科物理情報工学専攻博士課程修了. 富士ゼロックス（株），ロチェスター大 学助手を経て, 現在山形大学大学院准教授. 専門は視覚情報処理, 色彩科学. 日本視覚学会, 日本色彩学会, 日本照明委員会会員.

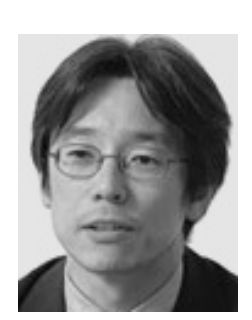

\section{坂田 勝亮}

女子美術大学芸術学部芸術学科

干252-8538 神奈川県相模原市南区麻 台 1900

1985 年早稲田大学大学院文学研究科博 士前期課程心理学専攻修了. 財団法人日 本色彩研究所, 秋田公立美術工芸短期大 学を経て, 現在女子美術大学芸術学部教授. 専門は視覚心理学, 色彩学. 日本色彩学会, 日本心理学会, 日本基礎心理学会, 日本 視覚学会, 米国光学会 $(O S A)$ 会員.

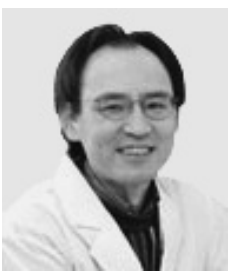

平澤 正勝 (正会員)

山形大学大学院理工学研究科

干992-8510 山形県米沢市城南 4-3-16 1994 年東北大学大学院理学研究科博士 課程修了. 東京大学物性研究所助手, 有 機エレクトロニクス研究所主任研究員 を経て, 現在山形大学大学院特任准教授. 専門は有機デバイス, レーザー工学. 日本照明学会, 応用物理学会会員. 